Article

\title{
Opportunities for Cross-Border Entrepreneurship Development in a Cluster Model Exemplified by the Polish-Czech Border Region
}

\author{
Joanna Kurowska-Pysz \\ Management and Engineering Production Department, University of Dąbrowa Górnicza, Str. Cieplaka 1c, \\ 41-300 Dąbrowa Górnicza, Poland; jkurowska@wsb.edu.pl; Tel.: +48-602-231-123 \\ Academic Editor: Adam Jabłoński \\ Received: 31 December 2015; Accepted: 18 February 2016; Published: 2 March 2016
}

\begin{abstract}
The subject of the paper is the analysis and evaluation of cross-border entrepreneurship development opportunities on the basis of cross-border cooperation, which has gradually evolved from consisting of bilateral partnerships to a networking model or even a cluster. The study conducted at the Polish-Czech border area indicates that, in terms of the development of cross-border cooperation, the economic sphere is lagging far behind social activities such as culture, education and tourism. At the same time, Polish and Czech enterprises are not sufficiently mobilized to develop cross-border entrepreneurship, although a number of support instruments in this regard have been proposed. Sustainable development of the border should take into account both social and economic aspects. An important research problem therefore becomes determining the possibility of boosting the development of cross-border entrepreneurship on the basis of the existing forms of cross-border cooperation, including cooperation in the social sphere. The aim of this paper is to define the conditions and opportunities for the development of cluster cooperation in the area of cross-border entrepreneurship. The author has attempted to resolve whether the intensity of cross-border cooperation can be a factor which mobilizes companies to develop their cross-border entrepreneurship and whether cross-border entrepreneurship can be further developed within the cluster model.
\end{abstract}

Keywords: sustainable development of the border region; cross-border cooperation; cross-border entrepreneurship; partnerships; cluster

\section{Introduction}

Processes occurring in the world economy have a significant impact on the functioning of enterprises, regardless of the scale of their business activity. Increased globalization favours the expansion of large transnational corporations, whereas simultaneously in the economy, there are many mechanisms stimulating the development of small and medium-sized businesses. Smaller enterprises, mostly operating on a regional or local scale, also have good prospects on the market, and also show a tendency for integration (also with larger companies), for example as clusters [1]. Clusters are a form of partnership aimed at developing cooperation between enterprises, but also local governments, academic institutions and business environment institutions, located in immediate geographical proximity and representing related sectors. These two strategic conditions are necessary to form appropriately strong bonds between the participants of a cluster.

An impulse for the development of any form of cooperation, including cooperation within the clusters, can be both the needs and expectations of interested entities as well as external factors encouraging integration. Particularly favourable system conditions, aiding the development of cooperation, are created in border regions. In contrast to many well-developed border towns in 
Western Europe or East Asia, Eastern Europe border regions are developing rather poorly, especially in economic and social terms. They are disadvantaged and at risk of marginalization, requiring special support. The reason is certainly the geopolitical situation in the communist bloc, which has pursued a specific policy of borderland development. Until the fall of the communist bloc, obtaining a passport was only possible for some citizens cooperating with the authorities. Until Poland and the Czech Republic joined the Schengen Zone on 21 December 2007, each crossing of the border was associated with the control of documents. Before freely crossing the border was allowed, the border area, as a militarily strategic zone, was excluded from priority economic and social investments, and it was patrolled by the army in the large part. In a social sense, crossing the border was seen as an extraordinary necessity, not as a privilege of border residents and other citizens. This possibility was exploited only in specific situations. The border was therefore divided and not united, which at present means the process of cross-border cooperation between Poland and the Czech Republic, despite its undeniable dynamism, is not progressing as fast as in other regions of the world.

Integration activities, stimulating the development of border areas, are undertaken both at the level of the European Union, as well as individually by neighbouring member states, which are in favour of cross-border business development and socio-economic integration of the neighbouring communities.

So far, in cross-border cooperation, both in terms of social as well as economic cooperation, bilateral partnerships are the dominant type of cooperation existing between local governments and NGOs, and occur much less frequently between enterprises. There is no doubt that bilateral cooperation between the same partners continuing for a long time strengthens cross-border relations, yet does not fully serve the development of border areas. In order to effectively counteract the development-related problems of these areas, it is both necessary to form new partnerships between entities that have not worked together before as well as develop networking opportunities. Currently, most examples of networking occur in the social sphere whereas at the economic level they occur only occasionally. In order to balance this trend, it is necessary to define mechanisms to encourage cross-border entrepreneurship development and economic cooperation of a networking nature that could develop as clusters.

Analysis of cooperative relations occurring in the borderland has encouraged the author to consider the opportunities for cluster cooperation development in these areas. It is fostered by both a natural tendency for cross-border integration, as well as the external conditions, resulting among other factors from the socio-economic policy of neighbouring border regions and the European Union's system support, e.g., in the form of the INTERREG VA 2014-2020 funds [2].

The aim of the paper is to define the conditions and possibilities for the development of cluster cooperation in the area of cross-border entrepreneurship. An example of Polish-Czech cross-border cooperation between Silesian Voivodeship (Poland) and the Moravian-Silesian Region (Czech Republic) was used to measure the level of development of cross-border entrepreneurship. The author has attempted to resolve whether the intensity of cross-border cooperation can be a factor that mobilizes businesses to develop their cross-border entrepreneurship and whether cross-border entrepreneurship can thrive in the cluster model.

In the studied area, qualitative research was conducted: desk research and quantitative research involving IDI, CATI, CAWI and CATI and PAPI data collection methods. In this paper, the author used qualitative research (IDI), implemented in 2014 by the TRITIA association and the Regional Development Agency in Ostrava, on a sample of 30 Polish and Czech companies. Research topics related to the motives and the process of the development of cross-border entrepreneurship and other conditions related to their activities at the border. As part of this study, several case studies were undertaken of companies developing their cross-border entrepreneurship, including the company run by the author in the field of consulting. In addition to these studies, the author has used her own research conducted by means of the CATI method with 14 companies from the voivodeship of Silesia and the Moravian country, identifying their level of interest in cross-border entrepreneurship, as well 
as their opinions about the barriers and benefits related to it. In order to identify potential regional specializations which can form the basis for the development of future cross-border clusters, the author also used her own qualitative research conducted in the years 2014-2015, including:

- $\quad$ survey methods such as: CATI, CASI and CAWI on a group of 466 Polish local government units and 199 Czech local government units for assessing the current state of Polish-Czech border cooperation, identification of factors shaping the development of this cooperation, the projected directions of this cooperation and the main actors of this cooperation,

- $\quad$ survey using PAPI method, giving the possibility of creating in Polish-Czech Euroregion Cieszyn Silesia-of a cross-border cluster in cultural and creative industries, which covered a total of 40 entities from Poland and the Czech Republic, declaring their intention to strengthen cross-border cooperation, including 18 Polish and Czech companies. These studies related to the nature and extent of cooperation with the entities in the neighboring country, the key benefits of cluster cooperation in the field of culture and creative industries as well as barriers to this process.

Conclusions from the study will serve as recommendations for entities responsible for cross-border cooperation policy (e.g., regional governments, business environment institutions) whose task is to create good conditions for the development of cross-border entrepreneurship.

\section{Cross-Border Territorial Partnerships as a Form of Inter-Organisational Cooperation in the Border Regions}

Territorial partnership is voluntary and is based on the agreement between at least three partners representing at least two of the three sectors: public, private and non-governmental. These partners maintain autonomy and jointly implement long-term measures for the benefit of a specific region. Within the framework of cooperation, they improve and monitor the partnership and maintain the principle of equality in the sharing of resources, responsibilities, risks and benefits [3]. The development of territorial partnerships in the 1980s contributed to the popularization of the local resources management model, involving-among others-the creation of more or less formal organizations uniting representatives of public, private and non-governmental sectors in a specific area $[4,5]$. Partnerships also developed through the process of European integration and the support of cross-border cooperation, as well as the pursuit to strengthen the competitiveness of peripheral and marginalized areas. Territorial partnerships bear a reference to cross-border cooperation.

The definition of cross-border cooperation was provided in the European Charter for Border and Cross-Border Regions (1981) [6], the European Outline Convention on Transfrontier Cooperation between Territorial Communities or Authorities (1980) [7] and the European Charter of Regional Self-Government (1997) [8]. Generally, it can be stated that cross-border cooperation is one of the forms of territorial cooperation of different types of units in the border regions, which might be related to all areas, including entrepreneurship. A common historical origin and other important similarities between neighbouring areas on the borderland (e.g., linguistic, cultural, constitutional, social or economic) may aid in joining forces to achieve common development goals.

Cross-border cooperation applies equally to the activities of local authorities at various levels, as well as to joint initiatives, e.g., non-governmental organizations or businesses. It aims to create cooperation networks at local and regional levels, as a result of which cooperation on economic matters can be fostered, while cultural and social barriers in local communities disappear [9].

The issue of partnerships was recognized, among others, in the regulation of EU structural funds [10]. Traditionally, partnerships are a mechanism for the transfer of development policy to lower levels of the hierarchy (top down policy). Partnerships are also agreements of entities at different levels of the hierarchy, providing interested parties with influence and participation in the development processes, both initiated at the lowest levels of cooperation (bottom up policy), as well as arranged at higher levels (as mentioned above, top down policy) [11].

The principles of entering into cross-border partnerships have been stipulated in the Council Regulation (EC) No. 1083/2006. Each country, depending on its needs and legislative capabilities, 
enters into partnerships with public authorities at various levels, or with other entities, including NGOs, which can act as economic and social partners [12].

Currently, partnership is most commonly associated with various forms of cooperation between institutions, entities and individuals in the implementation of common social, economic or environmental goals. The essence of partnership consists in finalizing an agreement (but also civil law or association agreement) by entities, institutions, organizations and individuals aimed at engaging all the concerned parties in actions aimed at optimal use of the available resources and stimulating multi-dimensional development, using various tools and cooperation mechanisms. The consequence of the concluded agreement is to undertake joint ventures (projects, programs) of a different nature, enabling achievement of common objectives.

An example of cross-border partnership are Euroregions-associations operating in the borderlands of two or more countries, specializing in cross-border cooperation [13]. The main aim of their activities is the removal of socio-economic inequalities, solving the problems of disadvantaged and peripheral areas, building mutual trust and cooperation across borders [14] as well as promoting cross-border entrepreneurship development and integration in other fields, e.g., education [15]. Such goals are pursued by Euroregion Cieszyn Silesia. This forum of cooperation covers the border areas of the Silesian Voivodeship (Poland) and the Moravian-Silesian Region (Czech Republic). In the Polish and Czech part, there are two associations whose members are municipalities, NGOs and enterprises engaged in Euroregion activity. Both active associations and their members have undertaken a series of cross-border projects, some of which were carried out with the support of European Union structural funds [16]. However, in the period following the completion of these projects, cooperation was continued and further developed [17]. An example of such integration trends, based on the implementation of earlier EU projects may be, among others, interest in creating a cross-border culture cluster in the Euroregion Cieszyn Silesia. It is one of the examples of partnership activities, consisting in the creation of local network structures or a cluster, based on the cooperation of persons, entities and institutions interested in the development of a given territory.

However, increasing trends to further strengthen cross-border relations to form a cluster can be observed, which allow for a departure from bilateral cooperation to multilateral interaction between the main actors in the cluster. Sectoral clusters are among the inter-organizational networks, which involve the transfer of knowledge [18] and other flows (material or information), as well as the development of relationships (formal and informal), of which the most important are social. In the networks of cooperation, the participation of enterprises, research units, administration [19], civil society and those responsible for environmental issues [20] is necessary. Due to the institutional and social nature of clusters, official relationships overlap here both structurally (between the cooperating parties) and organically (between the people involved in the cooperation). Another aspect is that friendly, neutral as well as hostile or competitive relationships [21] can form in the cluster. The number of links, the types of actors and the industry specializations of the cluster have been captured by M. Hennning, J. Moodysson and M. Nilsson [22]. They emphasized how important it is to direct cross-organizational cooperation, including clustering, according to regional specializations. This leads to the involvement of entities responsible for shaping regional policy, going beyond the typical areas of clusters' operation. This coupling of actions drives the competitive advantage of the region, and various measures to strengthen inter-organizational cooperation in sectoral clusters were also included in this paper. The author focuses on the example of the eastern part of the Czech-Polish border, i.e., Euroregion Cieszyn Silesia, where a clear regional specialization in the field of culture and creative industries is being established, and entities responsible for the regional policy of Poland and the Czech Republic as well as for cross-border policy (i.a. TRITIA) are involved in integration policy. An example would be, among others, interest in creating a cross-border cluster of culture and creative industries in the Euroregion Cieszyn Silesia. 


\section{Clusters as an Advanced Form of Cross-Border Cooperation Development}

The territorial and integrative context of cluster activity is an important prerequisite to considering the possibility of cross-border cluster development in borderlands. Low levels of socio-economic development of border areas indicate the need for greater emphasis on the economic aspects of integration and cooperation, which so far have definitely been outweighed by the social aspects. Not only in borderland regions, an important feature of innovative and competitive organizations is their propensity for cooperation, including the development of various types of network relationships [23-25].

These are structures in which individuals and groups, acting independently, collaborate towards achieving a common goal [26]. This cooperation may take the form of various types of territorial partnerships, single and multi-sector, as well as networks and clusters $[27,28]$. The degree of institutionalization of clusters is varied [29]. They involve mainly businesses, but also institutions of operating in varied business environments, local governments at various levels, NGOs, local development agencies, schools, banking institutions and the R\&D sector, including scientific bodies.

A cluster is a geographic concentration of interconnected enterprises, specialized suppliers, service providers, businesses operating in related sectors and associated institutions in particular fields, competing with each other but also cooperating [30]. The cluster can also be defined as geographically limited agglomerations of enterprises [31], together generating synergistic effects. There are many other similar definitions [32,33]

A cluster is defined by the following key elements: the cluster members and the relationships between them, generated knowledge and innovation, and the economic impact (economic effect) of cluster activities.

The process of cluster development in a border area can be considered as one of the new challenges of cross-border cooperation, which is currently evolving from consisting of bilateral partnerships towards a networking model. Clusters serve in the cooperation of entities within a certain geographical area, which provides the ability to initiate and develop direct contact between the participants in the network. Another premise is the possibility of achieving synergy through joint action for the benefit of the given community and territory. Clusters as a form of networks are often characterized by loose and voluntary relationships, involving the transfer of resources between individuals, including the transfer of information and knowledge [34]. Clusters are also characterized by specialization in a particular sector or industry, affinity of the technologies and skills used, consistency between objectives and products or services offered on the market [35].

In the long term, the success of the cluster is determined by the quality of internal collaboration and having common objectives among its participants. It is also important to appoint a leader who is able to animate and develop cooperative relationships within a cluster, despite many obstacles and restraints that constrain this process.

Natural tendencies for integration, the popularity of inter-organizational cooperation, as well as the availability of mechanisms supporting this cooperation (including structural funds) are certainly important factors conducive to the development of cluster structures in border regions, which concern external entities interested in the development of clusters and networks. The European Commission indicates that the regions which combine risk capital, competence and high quality research on a broad portfolio of clusters have a chance to become nodes of innovation [36]. Such development impulses are important in border regions, often peripheral and marginalized, mostly characterized by lower indicators of economic and social development, also with weaker potential than preferably located areas. For these regions, especially important is access to valuable knowledge and the ability to overcome various types of barriers to development, including barriers in cross-border relations, thanks to which economic and social cohesion of borderland is fostered. In the process of "learning" in border regions and developing cross-border cooperation, an important role might be served by clusters.

The location of the cluster in cross-border environments where various forms of cooperation are very popular, including cross-sector partnerships involving entities from neighbouring countries, could 
become a catalyst for closer relations between cluster members. In general, the scope and objectives of cooperation in the cluster are defined by partners themselves (entrepreneurs, local governments, NGOs, etc.), but in the border region the broader context of cluster activity should be taken into account-the desired and expected development of cross-border cooperation. Clusters have the chance to become effective, future-oriented forms of cross-border cooperation which will contribute to a better use of the diverse potential of the entire border, effectively overcoming barriers in building mutual relations between neighbouring communities, as well as achieving more dynamic development of the whole cross-border region. The development of cluster structures in the borderland contributes to overcoming the negative aspects of the peripheral location of border areas, the use of the development opportunities arising from the proximity of the neighbouring country, promoting the idea of European unity and international cooperation, the spreading of the socio-cultural influences and innovations, among other benefits

\section{Cross-Border Entrepreneurship and Cross-Border Cooperation}

Entrepreneurship is a result of the development of social relations. Entrepreneurs strive to create value [37] and to improve their own personal well-being, but also that of society [38,39], which is reflected in the wide economic development of the area in which they operate. The development of entrepreneurship can be one of the indications of cross-border cooperation, leading to the improvement of the socio-economic situation of marginalized areas. Social activities have an important role to play here as well (e.g., joint planning at a cross-border level, events, cultural activities, education, investment in infrastructure on both sides of the border, etc.), which makes the integration process more natural and versatile [40]. According to P. Drucker, entrepreneurship as a mode of behaviour, can be attributed to individuals, a team or institution [41]. Thus, in the regional system, the development of entrepreneurship is the resultant behaviour of many entities with different business objectives. In this sense, entrepreneurship refers not only to the business itself, but also to local governments, non-governmental organizations or other entities in the business environment [42]. Of great importance in the process of enterprise development are such factors as education and quality of intellectual capital, intensity and diversity of support for growing businesses, the activity of local and regional authorities in creating conditions conducive to economic revival, the social attitude of residents and the tradition of entrepreneurship in the given area.

Cross-border entrepreneurship concerns many indications of economic activity beyond borders, which usually include various forms of partnerships [43]. The cross-border location of economic entities means that it is often not necessary to register a business activity on the other side of the border, or else business activity is carried out there through another entity in the neighbouring border region.

The conceptual importance of cross-border entrepreneurship is thus determined by: the term cross-border, which means exceeding national borders; and its transboundary nature, which entails regular and continuous contact beyond national borders, with daily (institutionalized or not) cooperation in the areas on both sides of the border [44].

Cross-border entrepreneurship represents an opportunity both for the development of the regions as well as individual enterprises. The relationship between cross-border entrepreneurship and cross-border cooperation is interdependent. On the one hand, cross-border cooperation stimulates the development of entrepreneurship in marginalized regions, but at the same time, entrepreneurship expanding across national borders is also an impetus for closer cross-border cooperation.

Cross-border entrepreneurship has an influence on capital, supply and sales markets, the search for business partners, transfer of knowledge and know-how, acquiring staff and other resources of interest to the partners on both sides of the border [45]. Cross-border entrepreneurship can also include cross-border clusters and cooperation networks. 


\section{Conditions for the Development of Cross-Border Entrepreneurship in the Silesian Voivodeship and the Moravian-Silesian Region}

The Silesian Voivodeship and the Moravian-Silesian Region are twin areas located on the Czech-Polish border, which for many years have been brought together through close cross-border cooperation. According to the data as of 31 December 2013, Silesian Voivodeship had a population of approximately 4.6 million and occupied an area of $12.333 \mathrm{~km}^{2}$, while GDP per capita at current prices amounted to 44.960 PLN (approx. 11 thousand Euro). On the other hand, the Moravian-Silesian Region was inhabited by approx. 1.2 million people and occupied an area of $5427 \mathrm{~km}^{2}$ and GDP per capita at current prices amounted to 325.963 CZK (12 thousand Euro) [46]. Despite the differences in the level of population and surface area, the economic potential of both regions is similar. In the report "Doing Business 2015", in terms of the conditions for conducting business, Poland was ranked 32nd place, while the Czech Republic 44th place for 189 countries assessed, while in terms of barriers in starting up a business, Poland was classified 85th, while the Czech Republic was ranked at 110th place [47].

In both countries, there exist similar business solutions. A comparative analysis shows that both in the Silesian Voivodeship, as well as in the Moravian-Silesian Region, a number of institutions operate which support developing companies. These are mainly technology parks and entrepreneurship incubators, as well as loan and delivery funds. In both regions, there are also grants from structural funds available, and additionally in these areas, there is the possibility of tapping into EU funds intended specifically for the development of borderlands which come from the Operational Programme of Cross-Border Cooperation Czech Republic-Republic of Poland 2007-2013 and the Operational Programme INTERREG VA Czech Republic-Poland 2014-2020. There are also funds available that are intended for other entities, e.g., local governments, NGOs, labour market institutions, etc. which are aimed at the development of cross-border entrepreneurship, among other goals.

Both regions (together with Opole Voivodeship-Poland and the Local Government Žilina Region-Slovakia) are members of the European Grouping of Territorial Cooperation TRITIA (TRITIA), which was established in 2013. In 2013, the implementation of the strategy for the system cooperation of the regions forming the European Grouping of Territorial Cooperation TRITIA was conducted, in which economic goals and the main tasks for achieving cross-border cooperation in the field of entrepreneurship were established [48].

The objectives and activities that foster the development of cross-border entrepreneurship are included in Table 1.

Table 1. Objectives and actions supporting the development of cross-border entrepreneurship initiated by European grouping of territorial cooperation TRITIA, Ltd. TRITIA.

\begin{tabular}{lll}
\hline \multicolumn{1}{c}{ Kind of Objectives/Support } & \multicolumn{1}{c}{ Discription of Activities } \\
\hline Overall objective & $\begin{array}{l}\text { Creating an environment for employment growth and the } \\
\text { development of cross-border economic space based on } \\
\text { entrepreneurship, geographic location, local human resources, } \\
\text { common history and the complementary strengths of all the regions }\end{array}$ \\
\hline Specific objectives & 1. $\quad \begin{array}{l}\text { Establishing conditions for the development and } \\
\text { institutionalization of the different elements of cooperation } \\
\text { leading to the establishment of cross-border economic space } \\
\text { Supporting the development of human resources and } \\
\text { administrative/institutional potential of the } \\
\text { cross-border region } \\
\text { Supporting cross-border initiatives in research, development } \\
\text { and innovation. }\end{array}$ \\
\hline
\end{tabular}


Table 1. Cont.

\begin{tabular}{|c|c|}
\hline Kind of Objectives/Support & Discription of Activities \\
\hline \multirow{11}{*}{ Selected forms of support } & Pooling and cooperation of cross-border clusters \\
\hline & 2. Cooperation of universities \\
\hline & $\begin{array}{l}\text { 3. Meetings institutionalisation of entrepreneurs from the } \\
\text { participating regions-brokerage event }\end{array}$ \\
\hline & $\begin{array}{l}\text { 4. The creation of cross-border economic forum } \\
\text { TRITIA—supporting the development of the business } \\
\text { community on the border }\end{array}$ \\
\hline & $\begin{array}{l}\text { 5. Promoting financial tools to support the SMEs sector and } \\
\text { institutions supporting entrepreneurship, enhancing the } \\
\text { attractiveness of the business environment and a culture of } \\
\text { innovation, together with raising the quality of public services } \\
\text { addressed to entrepreneurs }\end{array}$ \\
\hline & Cross-border development of the labour market \\
\hline & $\begin{array}{l}\text { 7. Coordination of cooperation of entities supporting } \\
\text { entrepreneurship, e.g., regional development agencies, } \\
\text { chambers of commerce, etc. }\end{array}$ \\
\hline & $\begin{array}{l}\text { 8. Activities undertaken within cross-border cooperation of } \\
\text { entities involved in R \& D and the entrepreneurs sector, aimed } \\
\text { at developing an innovative environment }\end{array}$ \\
\hline & $\begin{array}{l}\text { 9. Cooperation in the creation of cross-border products } \\
\text { supporting a culture of innovation (e.g., education activities, } \\
\text { academic entrepreneurship, cross-border innovation portals, } \\
\text { joint actions aimed at implementing innovation strategies, etc.). }\end{array}$ \\
\hline & $\begin{array}{l}\text { 10. Investment in public infrastructure necessary to ensure the } \\
\text { development of entrepreneurship and innovation (science and } \\
\text { technology parks, entrepreneurship incubators, industrial } \\
\text { parks, innovation centres, etc.). }\end{array}$ \\
\hline & $\begin{array}{l}\text { 11. Cooperation in other areas of } \mathrm{R} \& \mathrm{D} \text { (research and } \\
\text { development), including fostering the integration of academic } \\
\text { and commercial spheres. }\end{array}$ \\
\hline
\end{tabular}

Source: own elaboration based on information about the project.

In 2014, TRITIA and the Regional Development Agency from Ostrava conducted a qualitative study of 30 young companies (15 Czech and 15 Polish companies, each of which have been in operation on the market for less than three years) among small and medium-sized enterprises in the Silesia Voivodeship and Moravian-Silesian Region. The study was conducted as part of the project "Sustainable economic activity", co-financed by the Operational Programme of Cross-Border Cooperation Czech Republic-Republic of Poland 2007-2013. Respondents for the study were recruited from among the companies leading innovation-oriented development activities and interested in developing cross-border business, benefiting from the support of entrepreneurship incubators, technology parks and other business institutions on the border. The research involved the development of case studies examining the company's development path with reference to cross-border interest in entrepreneurship and integration with other companies operating on the border. In-depth personal interviews (IDI) were also conducted as part of the study, and the respondents were asked, among others, questions regarding the following issues:

- the process of creating companies and business conditions in the market,

- the scope of the offer and its development,

- the main market, including the market focused on cross-border cooperation,

- interest in the development of intellectual capital in their companies,

- cooperation with universities,

- interest in the sectoral integration and cross-border cooperation,

- recommendations on the stabilization of the company on a cross-border market.

The results of this study are shown in Tables 2-6. 
Table 2. Structure of cooperation.

\begin{tabular}{|c|c|}
\hline \multicolumn{2}{|c|}{ Structure of Cooperation } \\
\hline Silesian Voivodeship (PL) & Moravian-Silesian Region (CZ) \\
\hline $\begin{array}{l}2 / 3 \text { of the surveyed companies were established } \\
\text { using a grant enabling unemployed people to start a } \\
\text { company. This implies the need to respect business } \\
\text { plans and running business activities mainly as a } \\
\text { self-employed person or hiring a few persons. Thus } \\
\text { the development of cooperation with other entities is } \\
\text { progressing rather slowly, as companies try to act } \\
\text { based on their own resources. The use of domestic } \\
\text { subsidies often restricts development cooperation. } \\
\text { Most companies have not given priority to acquiring } \\
\text { enterprises for cooperation purposes from } \\
\text { cross-border market so far. }\end{array}$ & $\begin{array}{l}\text { For small businesses the biggest expense are wages, } \\
\text { and therefore they restrict employment to a } \\
\text { minimum, while they still prefer close relationships } \\
\text { with regular suppliers and close associates. In this } \\
\text { way permanent cooperative groups of enterprises are } \\
\text { formed whose business activity is a part of a common } \\
\text { product or service. Until present, this cooperation has } \\
\text { been focused on the regional market, companies are } \\
\text { not looking for business partners on cross-border } \\
\text { market, but some companies are already present in } \\
\text { this market as producers. }\end{array}$ \\
\hline
\end{tabular}

Source: own elaboration based on data from the project.

Table 3. The scale of business activity.

\begin{tabular}{cc}
\hline \multicolumn{2}{c}{ The Scale of Business Activity } \\
\hline Silesian Voivodeship (PL)
\end{tabular}

In foreign markets, 6 companies operate (more than $1 / 3$ of respondents), and for one of them exports account for $90 \%$ of revenue. Three companies operate on a cross-border market, the remaining three are suppliers for Czech companies. In the vast majority, however, the domestic market is their dominant market, although all Polish respondents are interested in the Czech market. Most companies declare that they are too weak to compete in the

In the foreign markets, 7 companies operate, 1 company already operates on a cross-border market, others are investigating this market. The companies claim that at the first stage of development they want to focus on the domestic market since they do not feel strong enough to enter foreign markets, including the cross-border market. cross-border market.

Source: own elaboration based on data from the project.

Table 4. Development of human resources.

\begin{tabular}{ll}
\hline \multicolumn{1}{c}{ Development of Human Resources } \\
\hline \multicolumn{1}{c}{ Silesian Voivodeship } & \multicolumn{1}{c}{ Moravian-Silesian Region } \\
\hline $\begin{array}{l}\text { Most respondents have used specialist training in } \\
\text { their field and entrepreneurship before starting their } \\
\text { business. These people have gained expertise before } \\
\text { they established the company. More than 1/3 of } \\
\begin{array}{l}\text { companies intend to continue specialist trainings also } \\
\text { in the scope of business activity. }\end{array}\end{array}$ & $\begin{array}{l}\text { Undertaking business activity was mainly driven by } \\
\text { the competence of the respondents and not different } \\
\text { types of incentives to establish a business. Despite the } \\
\text { wide range of courses, trainings, etc. self-education is } \\
\text { the dominant mode, as well as investing in language } \\
\text { learning. Companies are also willing to benefit from } \\
\text { the offer of free consultations, conferences and } \\
\text { meetings funded by, among others, } \\
\text { cross-border funds. }\end{array}$ \\
\hline
\end{tabular}

Source: own elaboration based on data from the project. 
Table 5. Collaboration with universities.

\begin{tabular}{ll}
\hline \multicolumn{1}{c}{ Cooperation with Universities } \\
\hline \multicolumn{1}{c}{ Silesian Voivodeship } & \multicolumn{1}{c}{ Moravian-Silesian Region } \\
\hline $\begin{array}{l}1 / 5 \text { of respondents cooperate with universities in } \\
\text { projects, R\&D services, and vocational education of } \\
\text { students. Much more popular is the cooperation with }\end{array}$ & $\begin{array}{l}\text { Nearly 2/3 of respondents cooperate with } \\
\text { universities with regard to research or educational } \\
\text { activities, e.g., organization of apprenticeships and } \\
\text { NGOs offering companies specific advisory support } \\
\text { regarding business development, consulting and } \\
\text { training. Universities lack such an offer. Through } \\
\text { these forms of cooperation, respondents have contact } \\
\begin{array}{l}\text { with cross-border partners, since universities and } \\
\text { non-governmental organizations often rely on } \\
\text { cross-border funds. }\end{array}\end{array}$ \\
$\begin{array}{l}\text { have been indicated. Cooperation with universities, } \\
\text { which are beneficiaries of cross-border projects gives } \\
\text { businesses access to partners from the border area. }\end{array}$ \\
\hline
\end{tabular}

Source: own elaboration based on data from the project.

Table 6. Willingness to integrate.

\begin{tabular}{ll}
\hline \multicolumn{1}{c}{ Willingness to Integrate } \\
\hline \multicolumn{1}{c}{ Silesian Voivodeship } & \multicolumn{1}{c}{ Moravian-Silesian Region } \\
\hline $\begin{array}{l}\text { The vast majority of respondents declare membership } \\
\text { or cooperation with trade or business associations, or } \\
\text { even clusters (1 company). }\end{array}$ & $\begin{array}{l}\text { Only one company is a member of a trade association, } \\
\text { and the others did not have such a need or did not } \\
\text { realize there was such a possibility. }\end{array}$ \\
\hline
\end{tabular}

Source: own elaboration based on data from the project.

The selected research findings presented above, because of the sampling mode (non-random), reflect only indicative trends in the development of young companies operating in the Silesian Voivodeship and Moravian-Silesian Region. The results indicate that the presence of the enterprise in the border area market does not mean that it automatically treats the neighbouring market as a natural expansion area. Awareness of the border is very strong among novice entrepreneurs. As companies are focused on overcoming the initial challenges in starting up their business and gaining the nearest market (mostly local), the prospect of cross-border market is quite remote for them. However, the tendency to cooperate with universities and the development of human resources, which contributes to improving the quality of human capital in the region, should be assessed positively [49].

In these studies, the author took personal part, since her Polish consulting company develops cross-border entrepreneurship in three aspects: by serving Czech customers, through the procurement of the suppliers from the Czech market and through the Polish-Czech consortium in which large orders are provided. In addition to the cited studies, in 2015, the author conducted her own qualitative research based on interviews with 14 companies (seven Polish and seven Czech companies) from the provinces of Silesia and Moravia that maintain business relationships across the border. The conclusions from the study are as follows:

- companies are interested primarily in acquiring specific cooperation partners (suppliers, customers) in the area of industry in which they specialize, they attach less importance to networking;

- companies expect cross-organizational cooperation, which will allow them to find market niches and will quickly manifest in their revenues and profits, and they are less interested in the exchange of knowledge, information, joint promotion, etc.;

- companies expect governments, scientific institutions and other business entities to take a partnership approach in the development of cross-border entrepreneurship, but in this field, the integration is still too weak and is characterized by differing interests; 
- companies indicate that the purchasing power of borderland residents is weak and competition in the market large, and therefore entering the same sector on the other side of the border can be afforded by only the most competitive enterprises,

- as a great aid in the development of cross-border entrepreneurship, companies point to direct contacts on the other side of the border, e.g., Polish-Czech staff, participation in the Polish-Czech Chamber of Commerce, participation in trade missions, participation in EU projects etc.

- as the key barriers to the development of cross-border entrepreneurship, companies point to: the lack of an effective system of support for such operations on the border, the lack of sufficient knowledge about the partner's market, currency risk, a similar structure of demand on both sides of the border and difficulties in producing a unique product, the bureaucracy, and the divergence in regulations.

The above-described attitude of the surveyed companies represents a big contrast to the above-mentioned actions supporting cross-border entrepreneurship which have been declared by TRITIA and Regional Development Agency of Ostrava. Similar projects supporting the development of Polish-Czech business have been undertaken by Czech-Polish Chamber of Commerce in Ostrava, Regional Development Agency in Ostrava, Innovation Support Centre VSB of Technical University in Ostrava, Entrepreneurs Club in the Castle of Cieszyn, Regional Chamber of Commerce and Industry in Bielsko-Biala and many other public and social entities, as well as local governments and their associations. Analysis of the initiatives undertaken by these entities indicates that many companies are monitoring the cross-border market, but do not have the courage to enter it. A meeting of Czech and Polish entrepreneurs, sponsored by the Czech-Polish Chamber of Commerce in Ostrava, is held annually in Ostrava and involves at least 150-200 companies from both countries, but it has not focused on the development of specific business investments. Similar opinions can be found among users of the Polish-Czech portal [50] which is a services platform in the field of cross-border economic cooperation for small and medium-sized enterprises. Another portal [51] dedicated for the inhabitants of the Polish-Czech border has a similar function. The development of cross-border business might be perceived by businessmen as an innovation in approaching the market, for which they are not yet ready. For many companies, innovative business solutions and the accompanying changes bring uncertainty which is difficult to deal with [52].

While cross-border cooperation is for many local governments and other organizations on both sides of the border a statutory requirement and a natural course of action, for other entrepreneurs it is meaningful only when real profits can be generated. In contrast to public or social bodies, entrepreneurs focus their activities primarily on the profit maximization of their own company, and only later on the interests of entities in their surroundings.

It should be noted, however, that despite general declarations about the need to support cross-border business, local governments do not see economic issues as a key area of cross-border cooperation. In 2015, the author conducted on the Czech-Polish border a comprehensive study assessing cross-border cooperation among a group of 466 Polish local government units and 199 Czech local government units (differences in the number of respondents are due to the size of the areas studied). The study was carried out by means of CATI, CAWI and CASI interviews. The elected results of this study are presented in Table 7. 
Table 7. Evaluation of Polish-Czech border cooperation by local authorities in the border area.

\begin{tabular}{|c|c|}
\hline Respondents form the Polish Part of Border Area (PL) & Respondents from the Czech Part of Border Area (SK) \\
\hline \multicolumn{2}{|c|}{ Assessment of cross-border cooperation in selected areas } \\
\hline culture $76.37 \%$ of positive answers & - culture $53.36 \%$ of positive answers \\
\hline $\begin{array}{l}\text { - } \quad \text { sport, recreation, tourism } 76.64 \% \text { of } \\
\text { positive answers }\end{array}$ & $\begin{array}{l}\text { - } \quad \text { sport, recreation, tourism } 49.03 \% \text { of } \\
\text { positive answers }\end{array}$ \\
\hline town-twinning $64.92 \%$ of positive answers & - $\quad$ town-twinning $44.34 \%$ of positive answers \\
\hline safety $54.38 \%$ of positive answers & - $\quad$ security $35.89 \%$ of positive answers \\
\hline $\begin{array}{l}\text { - environmental protection } 50.76 \% \text { of } \\
\text { positive answers }\end{array}$ & $\begin{array}{l}\text { - environmental protection } 30.13 \% \text { of } \\
\text { positive answers }\end{array}$ \\
\hline economic cooperation $38.55 \%$ of positive answers & - $\quad$ economic cooperation $22.92 \%$ of positive answers \\
\hline \multicolumn{2}{|c|}{ Selected factors shaping the development of cross-border cooperation } \\
\hline $\begin{array}{l}\text { - the quality of interpersonal relations } 77.02 \% \text { of } \\
\text { positive answers }\end{array}$ & $\begin{array}{l}\text { - the quality of interpersonal relations } 65.97 \% \text { of } \\
\text { positive answers }\end{array}$ \\
\hline $\begin{array}{l}\text { - joint acquisition of EU funds } 80.92 \% \text { of } \\
\text { positive answers }\end{array}$ & $\begin{array}{l}\text { - joint acquisition of EU funds } 50.53 \% \text { of } \\
\text { positive answers }\end{array}$ \\
\hline historical affinity and geographical proximity & - $\quad$ historical affinity and geographical proximity \\
\hline $47.04 \%$ of positive answers & $59.76 \%$ of positive answers \\
\hline $\begin{array}{l}\text { the economic interests } 24.30 \% \text { of } \\
\text { positive answers }\end{array}$ & $\begin{array}{l}\text { - the economic interests } 22.85 \% \text { of } \\
\text { positive answers }\end{array}$ \\
\hline \multicolumn{2}{|c|}{ The projected growth rate of the Polish-Czech border cooperation in the next 10 years } \\
\hline $\begin{array}{l}\text { - cooperation will continue to develop-53.33\% of } \\
\text { positive answers }\end{array}$ & $\begin{array}{l}\text { - cooperation will continue to develop- } 49.95 \% \text { of } \\
\text { positive answers }\end{array}$ \\
\hline $\begin{array}{l}\text { cooperation will remain at a similar level-39.36\% } \\
\text { of positive answers }\end{array}$ & $\begin{array}{l}\text { cooperation will remain at a similar level- } 38.80 \% \\
\text { of positive answers }\end{array}$ \\
\hline $\begin{array}{l}\text { - cooperation will disappear- }-4.37 \% \text { of } \\
\text { positive answers }\end{array}$ & $\begin{array}{l}\text { - cooperation will disappear- } 7.90 \% \text { of } \\
\text { positive answers }\end{array}$ \\
\hline $\begin{array}{l}\text { - there will be no cooperation- }-2.94 \% \text { of } \\
\text { positive answers }\end{array}$ & $\begin{array}{l}\text { - there will be no cooperation-3.36\% of } \\
\text { positive answers }\end{array}$ \\
\hline \multicolumn{2}{|c|}{ Projected development directions of Polish-Czech border cooperation in the next 10 years } \\
\hline $\begin{array}{l}\text { - } \quad \text { sports, recreation and tourism } 21.48 \% \text { of } \\
\text { positive answers }\end{array}$ & $\begin{array}{l}\text { - } \quad \text { sports, recreation and tourism } 15.89 \% \text { of } \\
\text { positive answers }\end{array}$ \\
\hline - culture $16.48 \%$ of positive answers & - culture $18.05 \%$ of positive answers \\
\hline $\begin{array}{l}\text { - } \quad \text { education and higher education } 5.19 \% \text { of } \\
\text { positive answers }\end{array}$ & $\begin{array}{l}\text { - } \quad \text { education and higher education } 10.47 \% \text { of } \\
\text { positive answers }\end{array}$ \\
\hline economic cooperation $5.81 \%$ of positive answers & - $\quad$ economic cooperation $3.47 \%$ of positive answers \\
\hline \multicolumn{2}{|c|}{ The dominant partners in the cross-border cooperation for local governments } \\
\hline - local governments $45.79 \%$ of positive answers & - $\quad$ Local governments $62.99 \%$ of positive answers \\
\hline NGOs $18.17 \%$ of positive answers & - $\quad$ NGOs $10.50 \%$ of positive answers \\
\hline - $\quad$ enterprises $4.83 \%$ of positive answers & - $\quad$ enterprises $2.96 \%$ of positive answers \\
\hline
\end{tabular}

Source: own elaboration based on data from the project.

The above data indicates that economic relations occupy a marginal position in cross-border relations as developed by the Polish and Czech local governments. Similar results were obtained for the Polish-Belarusian-Ukrainian border area [53]. This is in contrast to the main assumptions of this paper concerning the development of border areas. Sustainable development of the border should take into account both social and economic aspects; meanwhile, currently cross-border cooperation focuses primarily on social issues. This is evident both in terms of the leading areas of cooperation (culture definitely outweighs the economy), as well as in the factors which are indicated as determinants of development of cooperation. In this case, the historical relationship or the quality of human relationships play much greater roles than common economic interests. The economy was also not listed among the most frequently indicated directions of development of cross-border cooperation in the next 10 years. It was outrun by sport, culture, tourism, etc. The study findings indicate that nearly half of the surveyed local authorities stated that cooperation would continue to develop. The dominant 
model of cross-border cooperation for the coming years will be primarily based on public partnerships and public-social partnerships, based on local governments and non-governmental organizations, whereas cooperation with enterprises attracts relatively little interest.

The results presented above indicate that young companies located on the Czech-Polish border are not sufficiently mobilized in the integration and development of cross-border entrepreneurship. At the same time, it is clear that in certain areas that cross-border cooperation is developing very dynamically (e.g., culture, recreation, tourism), which also points to the economic potential of these industries. In 2014, the author conducted research on the possibility of establishing in Polish-Czech Euroregion Cieszyn Silesia a cross-border cluster of culture, which would have a sectoral nature [54,55]. In this cluster, the participation of governments, NGOs, scientific institutions and companies operating in the broadly defined field of culture, including creative industries (enterprises were the least represented in this group). Qualitative research (CAWI interviews) consisted of 20 entities from Poland and the Czech Republic, which fulfilled the requirements of participation in the potential cluster and declared their willingness to strengthen cross-border cooperation in the field of culture. Studies have shown that a key prerequisite for integration measures are the benefits which the respondent can derive from this cooperation. Nearly $68 \%$ of respondents said they are interested in cooperation in the field of culture and creative industries within the transboundary cluster, about $7 \%$ were not interested and $25 \%$ had no opinion on this subject. According to the study, despite the fact that in this area creative industries are developing rapidly, cultural cooperation associated more with the social rather than the economic sphere might become a platform for the further development of clusters. The establishment of such clusters is dependent of the potential cluster participants finding some distinct advantages in this form of integration.

This is confirmed by the opinions of the companies, extracted from the above studies by the author, in the sector of culture and creative industries (18 entities, including cinemas, theatres and cabarets, studios of design arts, museums and regional chambers, design studios, graphic and advertising studios, computer game developers, craftsmen, folk artists, media). These entities were asked about the following issues:

- the nature and extent of cooperation with entities of the neighbouring country,

- $\quad$ key benefits of cluster cooperation in the field of culture and creative industries as well as barriers to this process.

According to those narrowly focused studies, potential participants in the cluster of culture and creative industries work mainly with local governments and public cultural entities, which are often the recipients of their offerings. This explains the important role of local governments and cultural bodies in the potential development of a cluster for culture and creative industries. Some of these entities also cooperate with NGOs working in related industries, as well as with the media (these tendencies are stronger on the Polish side than on the Czech side). This fact also bodes well in terms of other potential clusters.

Greater interest in entering into clusters exists on the Polish side, where this form of cooperation is more popular, and also more companies declare interest in the Czech market and its customers. Therefore, efforts to strengthen cross-border cooperation in the form of a cluster would require more support from the Czech side for the very idea of further integration, and perhaps a better understanding of the meaning and purpose of such measures. A prerequisite for mobilizing cluster cooperation should be a better understanding of its benefits for each party.

The studied entities were asked questions about the evaluation of the benefits which can be accrued from closer cooperation in the sector of culture and creative industries within the cluster. The respondents answered that these might include the following benefits:

- better joint promotion of the offer among customers around the border and reaching new groups of recipients,

- the possibility of joint acquisition of EU funds for cross-border projects, 
- mutual compensation of resources and other forms of mutual assistance within the framework of ongoing business operations,

- joint training of staff and improving of standards of operation and exchange of know-how in the cultural and creative industries,

- optimization of the costs of economic activity.

The key barriers to cluster cooperation included:

- lack of funds for projects in the cluster,

- differences in the goals of individual parties' activities,

- low level of knowledge of potential partners and lack of confidence in them,

- the lack of real involvement of partners in the activities of the cluster.

\section{Prospects for the Development of Cross-Border Entrepreneurship in the Cluster Model}

As indicated by the above-described study, cross-border entrepreneurship is developing much more slowly than cross-border cooperation in social areas such as culture, sports, tourism or education. Efforts to expand the transboundary market are much weaker among companies, and the trend for integration of border communities at various levels is only indirectly related to the economy. It seems, however, that economic issues which are seemingly distant from social issues in practice are interconnected, as can be demonstrated, among other factors, by the cross-border cultural cluster mentioned above, also encouraging cooperation between entrepreneurs from the creative industries.

Assuming that a cross-border cluster should be cross-sectoral and, therefore, should integrate both businesses as well as local governments, non-governmental organizations and scientific bodies, a thesis can be put forward that the areas in which cross-border entrepreneurship may develop in a cluster model are those forms of cross-border cooperation that are developing most dynamically at present on the border. Cross-border cooperation in the form of various types of partnerships could therefore be the basis for further integration within the cluster model. Owing to extended cross-border cooperation, entities operating on the border understand the importance and benefits of integration activities. They can use this mechanism to achieve their own benefits, and thus for meeting the development needs of the whole border area. It can therefore be concluded that cluster initiatives on the Czech-Polish border, which immediately precede the formation of a cross-border cluster, should have their origin in cooperation of a social nature (e.g., in the fields of culture, sports, tourism, etc.). This is due to the fact that, in this area, the strongest integration processes take place, which can become a catalyst for the future development of the cluster. For the currently dominant, solid bilateral partnerships, cooperation development will be represent much added-value, mobilizing efforts to establish a cluster.

While companies do not feel strong enough to independently develop cross-border entrepreneurship, in these areas where the activities of companies on the border are connected with cross-border cooperation of a social nature, further integration is possible.

The economic development of the border region should be attended to by all the key stakeholders of the two neighbouring countries. The creation of a cross-border cluster should involve primarily entities conducting business activities (including companies, social organizations, public and government institutions providing some paid services and some schools and the media); there is also a place for institutions and non-profit organizations and the broad business- and social-related environment. Without a doubt, the formation of the cluster should be based on the specializations relevant to the border region, because in this way the economic interests of its constituent bodies go hand in hand with the interests of the region. Such a cluster can seek support in the regional environment and can draw on various types of support mechanisms of a systemic or individual nature [56]. Currently, by the example of the Czech-Polish border, and especially the voivodeship of Silesia and the Moravian-Silesian country, culture and creative industries can be pointed to as two key areas of integration. As mentioned above, the tendency for cluster cooperation on the Czech-Polish 
border is mainly centred on the Polish side, but more and more also Czech entrepreneurs are gaining interest. Two cluster initiatives are already in place, the so-called Silesian Cluster of the Design in Cieszyn and the Locomotive of Culture in Bielsko-Biala [57] which intend to open up cross-border cooperation. An exemplary model of cluster cooperation in the sector of culture and creative industries is shown in Table 8. In Table 9 we can find recommended market segmentation and description of the role of participants in the cross-border cluster of culture and creative industries.

Table 8. Proposed areas of cross-border cooperation and cross-border entrepreneurship possible for the development of a cluster in the cultural sector.

\begin{tabular}{|c|c|c|c|}
\hline \multicolumn{4}{|c|}{ Cultural Cluster } \\
\hline Public Sector & NGO Sector & Scientific Sector & Commercial Sector \\
\hline $\begin{array}{l}\text { Local governments, } \\
\text { community centres, } \\
\text { theatres, museums, } \\
\text { libraries, cinemas, art } \\
\text { schools, points of } \\
\text { cultural information and } \\
\text { virtual platforms of } \\
\text { cultural information etc. }\end{array}$ & $\begin{array}{l}\text { NGOs operating in the } \\
\text { sphere of culture, e.g., } \\
\text { music and dance groups, } \\
\text { associations cultivating } \\
\text { folklore and folk culture, } \\
\text { associations of amateur } \\
\text { artists etc. }\end{array}$ & $\begin{array}{l}\text { Research units conducting } \\
\text { research and training in the } \\
\text { fine arts, humanities and } \\
\text { social sciences }\end{array}$ & $\begin{array}{l}\text { The media, commercial } \\
\text { cultural institutions, } \\
\text { companies from the creative } \\
\text { industries sector, event } \\
\text { companies, artistic } \\
\text { management companies etc. }\end{array}$ \\
\hline
\end{tabular}

Source: own elaboration based on data from the project.

Table 9. Recommended market segmentation and the role of participants in the cross-border cluster of culture and creative industries.

\begin{tabular}{cl}
\hline Group & \multicolumn{1}{c}{ Description of the Group } \\
\hline Freelancers & $\begin{array}{l}\text { Independent developers, not employed on a full-time basis } \\
\text { in culture or in the creative industries, e.g., actors, dancers, } \\
\text { musicians, sculptors, painters and writers. This group } \\
\text { plays an important role in the cluster, since it creates a } \\
\text { crude substance (e.g., manuscript), which may } \\
\text { subsequently be processed (e.g., in the form of a book). } \\
\text { Cooperation within the cluster can help them in the } \\
\text { dissemination of work to a wider audience. }\end{array}$ \\
\hline
\end{tabular}

In the sector of culture and creative industries, there are many small and large companies, few middle-size ones. This is due to the specificity of the industry. Small companies usually invest in niches, while the largest companies operate in sectors oriented on typically

Micro Businessmen and Industry giants commercial activities, e.g., music, publishing, television or IT and often create powerful multi-sectoral, international conglomerates. Cooperation in the cluster can help smaller entities to compete with the "industry giants". The key is to engage in joint activities with appropriate partners, having complementary competencies and resources.

Centres shaping the knowledge and competencies of creative people, educating personnel for companies (from the creative sectors, and not only), creators and performers of culture as well as teaching staff, who communicate their

Centres of creative education knowledge and skills to the next generation. An important role is played here by academic centres educating professional artists and different kinds of entities operating to stimulate the creativity of society (e.g., courses in design, sewing, etc.). 
Table 9. Cont.

\begin{tabular}{|c|c|}
\hline Group & Description of the Group \\
\hline Public cultural institutions & $\begin{array}{l}\text { Museums, cultural centers, libraries, theaters, cinemas, } \\
\text { concert halls, galleries and historic buildings, conducting a } \\
\text { whole spectrum of socio-cultural activities, providing } \\
\text { visitors a variety of cultural forms of entertainment (e.g., } \\
\text { the performances, festivals, music concerts), acquiring } \\
\text { knowledge and new skills (e.g., craft workshops, drawing), } \\
\text { as well as developing their creative expression. Their offer } \\
\text { attracts residents, domestic and foreign tourists, as well as } \\
\text { artists looking for possibilities of establishing contacts with } \\
\text { other artists or just inspiration for the development of their } \\
\text { own work. }\end{array}$ \\
\hline Gatekeepers & $\begin{array}{l}\text { Persons or entities that determine which products is } \\
\text { launched on the market, e.g., art gallery manager, chief } \\
\text { editor of the publishing house, the artistic director of the } \\
\text { theatre, etc. }\end{array}$ \\
\hline Creative hidden people & $\begin{array}{l}\text { Talented people, who use their talent to work for entities } \\
\text { outside the creative industries. They occupy positions in } \\
\text { the project departments (designers, architects), marketing } \\
\text { (copywriters, graphic designers), IT (IT specialists), as well } \\
\text { as in other spheres, where their creative abilities are used. }\end{array}$ \\
\hline $\begin{array}{l}\text { Non-governmental organizations } \\
\text { (NGOs) }\end{array}$ & $\begin{array}{l}\text { Organizations of authors, but also those who want to work } \\
\text { to strengthen these sectors in the region. These } \\
\text { organizations are often involved in the development of } \\
\text { socio-cultural heritage of the given region, including } \\
\text { support of cooperation and integration in the environment } \\
\text { of creators, promoting the work of young talents, } \\
\text { supporting public participation in culture and its activity } \\
\text { with respect to fostering national heritage, promotion of } \\
\text { cultural heritage of a region in the country and abroad. }\end{array}$ \\
\hline Public authorities & $\begin{array}{l}\text { Public authorities can initiate and support the } \\
\text { development of creative industries in the region in many } \\
\text { different ways, both directly (e.g., through financing or } \\
\text { co-financing of business, science and culture-related } \\
\text { activities) as well as indirectly, reinforcing the environment } \\
\text { in which these entities operate. }\end{array}$ \\
\hline
\end{tabular}

Source: own elaboration [57].

Cooperation of organizations, commercial entities and institutions within the cluster of culture and creative industries fits perfectly with the determinants of cross-border cooperation as well as cross-border entrepreneurship. In terms of cross-border cluster operation, one can talk about further integration within a specific industry, sector e.g., culture, as well as the creation of mechanisms to encourage improvement of competitiveness and development of entities operating within a cluster. So far, there are not many examples of networking available. This may be due to many reasons: too strong an impact of barriers hindering this type of cooperation in the border area, and insufficient awareness of the benefits, advantages and conditions of networking cooperation.

Although the issue of partnership and sustainable cooperation is not an unfamiliar subject to any of the entities operating on the border (e.g., due to the large number of cross-border projects in different areas), among the companies there is a lack of spontaneous tendency to develop cross-border entrepreneurship. While the majority of surveyed companies declare that they are interested in such cooperation, they do not take any actions towards its effective establishment. It is a large dissonance compared to the intensive cross-border cooperation occurring in the social sphere in terms of culture. As the author recommends, it is therefore possible to draw on the good cooperation that exists between 
local governments in order to intensify economic relations. Such opportunities have emerged on the basis of previous studies on the establishment of transboundary cultural clusters. Research cited in this study confirms the important role local governments and the non-governmental sector has in the cross border development entrepreneurship of which can be transferred to enterprises. Extremely important is the education of potential participants of networks and clusters in terms of the specifics of this form of cooperation.

\section{Conclusions}

Cross-border entrepreneurship is an important aspect in the development of cross-border cooperation, which should contribute to ensuring there are equal development opportunities in peripheral areas at risk of marginalization. It is favoured by both natural integration trends in the border regions as well as the high availability of EU funds from the INTERREG program for the development of cross-border cooperation. In the studied area of the Czech-Polish border, effects of cross-border cooperation are clearly visible in the social sphere, primarily in the fields of culture, education, sports and tourism, administration, etc. However, this cooperation has developed to a much lesser extent in the economic sphere. For most companies operating in border regions, the markets of neighbouring countries are treated equally to other, much more distant foreign markets. It is difficult to identify clear trends for economic cooperation here.

The results of research and several years of involvement by the author in cross-border entrepreneurship, from a scientific and practical point of view, show that the development of cross-border cooperation-supported by local authorities-is limited to bilateral contact and projects. It is difficult to indicate a direction that allows for further strengthening of cooperation in the economic field, although further cluster cooperation seems a natural path.

Despite a series of actions aimed at systematic promotion of economic cooperation on the borderline, it is difficult to identify a significant number of such examples in Silesia Voivodeship and the Moravian-Silesian Region. This is in contrast to the strategy of cross-border cooperation for the border area, which has been implemented since 2013. In this document, economic cooperation is of key importance. Another real problem of cross-border cooperation is the stability of partnerships and lack of tendency to transform bilateral cooperation into networking cooperation. This means that cooperation between the same partners strengthens, but it does not expand to other entities. In these circumstances, cluster cooperation can be a model especially worth promoting among all entities interested in border development, among local governments as well as non-governmental organizations and entrepreneurs.

Although sustainable development of the border should be based on both social and economic processes, the sphere of entrepreneurship is now clearly ignored. It can be seen i.a. in the results of research carried out among local governments. They do not appreciate the economic aspects of cross-border cooperation, and the most promising directions of further integration are considered to be culture, education, tourism, etc. These sectors, however, also have certain economic potential, which means that there are opportunities for the involvement of entrepreneurs in cross-border cooperation in these areas.

The study results confirmed that between the Polish and Czech companies operating in the border area, there are differences in developmental processes, approaches to businesses, types of offerings, etc. This is not conducive to the natural processes of integration. It can therefore not be said that the chances of economic integration in each of the branches are identical.

In trying to solve the research problem relating to the possible development of cross-border entrepreneurship on the Polish-Czech border, the author turned to the concept of cluster cooperation, which has been more developed on the Polish side. Prospects for the development of clusters on the Polish-Czech borderland have been linked with the sectors that are developing most quickly in this area, i.e., the sector of culture and creative industries. As the second criterion, the author took into account the involvement of partners from different sectors: administration and local government, 
science and non-governmental organizations from both sides of the border. The studies conducted in this field have shown that culture and creative industries is the sphere where the entities of the Polish and Czech border areas see the greatest opportunities for further integration.

In the opinion of the author, the catalyst for cross-border entrepreneurship, at least in some sectors (e.g., in the field of creative industries), may centre on the very sophisticated cross-border cooperation at the public and social levels (i.e., the cooperation of local governments and non-governmental organizations), in which enterprises operating on each side of the border can be engaged. It also gives impetus to further expansion of this cooperation and transforming bilateral relationships to ones based on networking and clustering. Such opportunities have already been verified by the author in previous studies analysing the conditions conducive to the emergence of cross-border cultural clusters.

According to the author, in the study area, it is difficult to extract natural tendencies and the desire of companies to develop cross-border entrepreneurship, but a factor that can boost economic integration is rapidly developing cross-border cooperation in the social field, e.g., in culture $[47,48]$ etc. Although it is not a universal solution that can be applied to any industry, at least in sectors distinguished by intense cross-border relations, including business entities in this cooperation can bring measurable results, reflected also in the development of the border area. The condition for this mechanism is the awareness of the benefits which both parties can gain from the development of co-operation, also including entrepreneurs. Another important consideration affecting the efficiency of cross-border cooperation that determines the participation of entrepreneurs is the creation of mechanisms for its further development, including the gradual transformation of bilateral agreements into networking and clustering cooperation.

In conclusion, as long as the sectors such as culture and creative industries (or other sectors in other border regions) will be indicated directly or indirectly according to regional specializations, whose development is supported by all stakeholders of cross-border cooperation (including i.a. governments, research bodies, NGOs and entrepreneurs), then the cross-border cooperation can be transformed into that of clusters. This cooperation has its origin in typically social activities (as mentioned above, EU bilateral projects implemented mainly by local governments and non-governmental organizations), but under favorable conditions, it can also extend to business activities that generate economic benefits and contribute to the development of cross-border regions by strengthening regional specializations.

Conflicts of Interest: The author declares no conflict of interest.

\section{References}

1. Bleeke, J.; Ernst, D. The way to win in cross-border alliances. Harvard Bus. Rev. 1991, 69, 127-135.

2. Program INTERREG VA Czech Republic-Poland 2014-2020. Available online: https://www.ewt.gov.pl/ media/5504/Program_INTERREG_V_A_Czechy_Polska.pdf (accessed on 15 November 2015).

3. The OECD Study on Local Partnerships, OECD, Paris 1990. Available online: http://www.oecd.org/ cfe/leed/theoecdstudyonlocalpartnerships.htm (accessed on 20 November 2015).

4. Ray, C. Neo-endogenous Rural Development in the EU. In Book Handbook of Rural Studies; Cloke, P., Marsden, T., Mooney, P., Eds.; Sage: London, UK, 2006; pp. 278-291.

5. Simard, J.F.; Chiasson, G. Introduction: Territorial Governance-A New Take on Development. Can. J. Reg. Sci. 2008, 31, 471-485.

6. European Chapter of Border and Cross-Border Regions. Available online: http://www.aebr.eu/files/ publications/110915_Charta_EN_clean.pdf (accessed on 15 November 2015).

7. European Outline Convention on Transfrontier Co-operation between Territorial Communities or Authorities. Available online: https://rm.coe.int/CoERMPublicCommonSearchServices/DisplayDCTMContent? documentId=0900001680078b0c (accessed on 15 November 2015).

8. European Charter of Regional Self-Government. Available online: http://www.cvce.eu/en/obj/ draft_ european_charter_of_regional_self_government_5_june_1997-en-78ae4dcf-6346-4aa8-8474-7535e4091bf7.html (accessed on 15 November 2015). 
9. Perkowski, M. Współpraca transgraniczna. Available online: http://www.prawoipartnerstwo.pl/stara/ publikacje/Wspolpraca.pdf (accessed on 15 November 2015). (In Polish)

10. Rozporządzenie Rady z 21 Czerwca 1999 r.; Wprowadzające Ogólne Przepisy Dotyczące Funduszy Strukturalnych nr 1260/1999/WE. Available online: http:/ /ec.europa.eu/regional_policy/sources/docoffic/ official/regulation/content/pl/02_pdf/00_1_sf_1_pl.pdf (accessed on 15 November 2015). (In Polish)

11. Geddes, M. Partnership Making Policy, Report: Enhancing the Capacity of Partnerships to Influence Policy; Available online: http:/ / www.oecd.org/cfe/leed/36279186.pdf (accessed on 15 November 2015).

12. Rozporządzenie Rady z 11 lipca 2006 r. nr (WE) nr 1083/2006, Ustanawiające Przepisy Ogólne Dotyczące Europejskiego Funduszu Rozwoju Regionalnego, Europejskiego Funduszu Społecznego Oraz Funduszu Spójności i Uchylające Rozporządzenie (WE) nr 1260/1999. Available online: http://www.oecd.org/ cfe/leed/36279186.pdf (accessed on 16 November 2015). (In Polish)

13. Lepik, K. Euroregions as mechanisms for strengthening cross-border cooperation in the Baltic Sea region. Trames 2009, 13, 265-284. [CrossRef]

14. Kramsch, O.; Hooper, B. Cross Border Governance in the European Union; Routledge: New York, NY, USA, 2004.

15. Perkmann, M. Policy Entrepreneurship and Multi-Level Governance. A Comparative Study of European Cross-Border Regions. Environ. Plan. C Gov. Policy 2007, 25, 861-879. [CrossRef]

16. Harguindéguy, J.; Bray, Z. Does cross-border co-operation empower European regions? The case of INTERREG III-A France-Spain. Environ. Plan. C Gov. Policy 2009, 27, 747-760. [CrossRef]

17. Kurowska-Pysz, J. Problem trwałości klastrów dofinansowanych ze środków Unii Europejskiej w aspekcie nowych uwarunkowań wdrażania projektów w latach 2014-2020. In Book Zarządzanie i inżynieria produkcji. Wybrane zagadnienia; Kurowska-Pysz, J., Ed.; Wydawnictwo Naukowe Wyższej Szkoły Biznesu w Dąbrowie Górniczej: Dą̧rowa Górnicza, Poland, 2015. (In Polish)

18. Trott, P. Innovation Management and New Product Development; Pearson Education Ltd.: Edinburgh, UK, 2008.

19. Etzkowitz, H. The triple helix. In University-Industry-Government Innovation in Action; Routledge: London, UK, 2009; pp. 15-22.

20. Carayannis, E.; Barth, T.; Campbell, D. The Quintuple Helix innovation model: Global warming as a challenge and driver for innovation. J. Innov. Entrep. 2012. [CrossRef]

21. Olesiński, Z. Zarządzanie Relacjami Międzyorganizacyjnymi; Wydawnictwo CH Beck: Warszawa, Poland, 2010. (In Polish)

22. Henning, M.; Moodysson, J.; Nilsson, M. Innovation and Regional Transformation. In From Clusters to New Combinations; Region Skane: Malmö, Spain, 2010.

23. Lazerson, M.; Lorenzoni, G. The Firms that Feed Industrial Districts: A Return to the Italian Source. Ind. Corp. Chang. 1999, 8, 235-265. [CrossRef]

24. Bathelt, H. Cluster Relations in the Media Industry: Exploring the "Distanced Neighbour" Paradox in Leipzig. Reg. Stud. 2005, 39, 105-127. [CrossRef]

25. Sheppard, E. Positionality and globalization in economic geography. In The Changing Economic Geography of Globalization: Reinventing Space; Giovanna, V., Ed.; Taylor \& Francis: Oxfordshire, UK, 2005.

26. Lipnack, J.; Stamps, J. The age of network. In Organizing Principles for the 21st Century; Oliver Wight Publication: Gloucester, UK, 1994.

27. Pachura, P. Analiza potencjału budowy efektywnych struktur transgranicznych sieci innowacyjnych na przykładzie województwa śląskiego oraz regionów Czech i Słowacji, Ministerstwo Rozwoju Regionalnego, Częstochowa 2009, 9. Available online: https://www.ewaluacja.gov.pl/Wyniki/Documents/2_059.pdf (accessed on 30 November 2015). (In Polish).

28. Brito, C.; Correia, R. Regions as networks. Towards a conceptual framework of territorial dynamic, Research Work in Progress. 2010, 357, pp. 20-23. Available online: http://www.fep.up.pt/investigacao/ workingpapers/10.01.18_wp357.pdf (accessed on 30 November 2015).

29. Fromhold-Eisebith, E.; Eisebith, G. How to institutionalize innovative clusters? Comparing explicit top-down and implicit bottom-up approaches. Res. Policy 2005, 34, 1250-1268. [CrossRef]

30. Porter, M. The Cooperative Advantage of Nations; Harvard Business Review: New York, NY, USA, 1990; Available online: http:/ /dl1.cuni.cz/pluginfile.php/50387/mod_resource/content/0/Porter-competitiveadvantage.pdf (accessed on 30 November 2015).

31. Rosenfeld, S.A. Community College/Cluster Connections: Specialization and Competitiveness in the United States and Europe. Econ. Dev. Q. 2000, 14, 51-62. [CrossRef] 
32. Almodovar, J.; Teixeira, A. Conceptualizing clusters through the lens of networks: A critical synthesis. FEP Working Papers, 2009. Available online: http://www.fep.up.pt/investigacao/workingpapers/ 09.07.15_wp328.pdf (accessed on 20 December 2015).

33. Maskell, P.; Kebir, L. What qualifies as a cluster theory? Available online: http://www3.druid.dk/ wp/20050009.pdf (accessed on 30 November 2015).

34. Lepik, K.L.; Krigul, M. Cross-border cooperation institution in building a knowledge cross-border region. Probl. Perspect. Manag. 2009, 7, 33-45.

35. Rialland, A. Cluster Dynamics and Innovation; IGLO-MP2020 Working Paper; Norwegian University of Science and Technology: Trondheim, Norway, 2009.

36. Ketels, C.; Lindqvist, G.; Sölvell, Ö. Strengthening Clusters and Competitiveness in Europe. The Role of Cluster Organisations, the Cluster Observatory, 2012. Available online: https:/ /www.google.com.hk/ url? $\mathrm{sa}=\mathrm{t \& rct}=\mathrm{j} \& \mathrm{q}=\&$ esrc $=\mathbf{s} \&$ source=web\&cd=1\&ved=0ahUKEwjatNi3wp7LAhVBhSwKHa9HCWcQFggb MAA \&url=http $\% 3 \mathrm{a} \% 2 \mathrm{f} \% 2 \mathrm{fwww}$. clusterportal-bw.de $\% 2$ fservice $\% 2$ fpublikationen $\% 2$ fclusterpolitik-undclusterpolitische-massnahmen $\% 2$ fpublikation $\% 2$ fPublikationen $\% 2$ fdownload $\% 2$ fdokument $\%$ 2fstrengthening- clusters-and-competitiviness-in-europe\%2f\&usg=AFQjCNGM483M6JL2-3T08HLuEWhUY NqvAA\&sig2=1S6kD_sy6cBB-vSU0J61Xw (accessed on 21 November 2015).

37. Hisrich, R.D. Entrepreneurship/intrapreneurship. Am. Psychol. 1990, 45, 209-222. [CrossRef]

38. Burns, P. Entrepreneurship and Small Business; Palgrave MacMillan: Houndmills, UK, 2007.

39. Davidsson, P. The domain of entrepreneurship research: Some suggestions. In Book Cognitive Approaches to Entrepreneurship Research; Katz, J.A., Shepherd, D.A., Elsevier, J.A.I., Eds.; Book Series: Advances in Entrepreneurship, Firm Emergence and Growth, Emerald Insight; Available online: http:/ / www.emeraldinsight.com/doi/book/10.1016/S1074-7540(2003)6 (accessed on 21 November 2015).

40. Schuler, R.S.; Tarique, I.; Jackson, S.E. Managing Human Resourses in Cross-Border Aliancess, Advances in Mergers and Acquisitions (Advances in Mergers and Acquisitions, Volume 3); Emerald Group Publishing Limited: Bingley, UK; pp. 103-129.

41. Drucker, P. Innovation and Entrepreneurship, Practice and Principles; Harper\&Row: New York, NY, USA, 1985.

42. Ābele, L.; Līduma, D.; Leitāne, I.; Mežinska, A. Analysis of factors forming competitive business environment in cross-border region. Econ. Manag. 2012, 17, 1308-1313. [CrossRef]

43. Smallbone, D.; Welter, F. Cross-border entrepreneurship. Entrep. Reg. Dev. Int. J. 2012, 24, 43-63. [CrossRef]

44. Reśko, D. Przedsiębiorczość transgraniczna w wybranych jednostkach terytorialnych pogranicza polsko-słowackiego. Stud. Reg. Lokalne 2010, 2, 121-131. (In Polish).

45. Smallbone, D.; Welter, F.; Xheneti, M. Cross-Border Entrepreneurship and Economic Development in Europe's Border; Edward Elgar: Cheltenham, UK; Northampton, MA, USA, 2012.

46. The project "Sustainable economic activities", co-financed by the Operational programme of cross-border co-operation Czech Republic-Poland 2007-2013. Available online: http:/ /www.egtctritia.eu/pl/projekty/ nasze-projekty/zrownowazona-dzialalnosc-gospodarcza (accessed on 21 December 2015).

47. Report doing business, World Bank Group 2015. Available online: http://www.doingbusiness.org/ (accessed on 21 December 2015).

48. The project "Strategies for System Cooperation of Public Institutions of Moravian-Silesian Region, the Voivodeship of Silesia and Opole" co-financed by the European Regional Development Fund under the Operational Programme of Cross-Border Cooperation Czech Republic - Republic of Poland 2007-2013. Available online: http:/ / www.slaskie.pl/strona_n.php?jezyk= pl\&grupa=9\&dzi=1312275679\& art=1312275911\&id_menu=455 (accessed on 21 December 2015).

49. Szczepańska-Woszczyna, K. Rola edukacji w rozwoju regionu, Polityka gospodarcza gminy (rozwój Zagłębia Dąbrowskiego wczoraj i dziś). Zeszyty Naukowe WSB 2001, 2, 149-159. (In Polish)

50. Services platform for cross-border cooperation between Czech and Polish SME. Available online: http:/ / www.cespolgroup.com/pl/ (accessed on 21 December 2015).

51. Platform for cooperation of Polish-Czech societies. Available online: http://www.anotak.info/pl/biznes (accessed on 21 December 2015).

52. Szczepańska-Woszczyna, K. Innovation process in the social space of the organization. Reg. Form. Dev. Stud. 2014, 3, 220-229. 
53. Klimczuk., A.; Klimczuk-Kochańska, M.; Plawgo, B. Współpraca transgraniczna małych i średnich przedsiębiorstw jako czynnik rozwoju regionalnego na przykładzie podregionu białostocko-suwalskiego i podregionu krośnieńsko-przemyskiego w Polsce, obwodu Zakarpackiego na Ukrainie oraz obwodu grodzieńskiego na Białorusi. In book Wspótpraca transgraniczna małych i średnich przedsiębiorstw jako czynnik rozwoju regionalnego; Plawgo, B., Ed.; Białostocka Fundacja Kształcenia Kadr: Białystok, 2015; Available online: http:/ / ssrn.com/abstract=2604198 (accessed on 21 December 2015). (In Polish)

54. Kurowska-Pysz, J. Assessment of trends for the development of cross border cultural clusters. Forum Sci. Oecon. 2014, 3, 31-51.

55. Kurowska-Pysz, J. Proces zarządzania wiedzą w klastrach-Kluczowe uwarunkowania. Mark. I Rynek 2015, 12, 17-23. (In Polish)

56. Thissen, M.; Oort, F.; Diodato, D.; Ruijs, A. Regional Competitiveness and Smart Specialization in Europe; Edward Elgar Publishing Limited: Cheltenham, UK, 2013.

57. Szultka, S. Klastry w Sektorach Kreatywnych-Motory Rozwoju Miast i Regionów; Polska Agencja Rozwoju Przedsiębiorczości: Warszawa, Poland, 2012. (In Polish)

(C) 2016 by the author; licensee MDPI, Basel, Switzerland. This article is an open access article distributed under the terms and conditions of the Creative Commons by Attribution (CC-BY) license (http:/ / creativecommons.org/licenses/by/4.0/). 